\title{
Key points of interbody fusion following surgical decompression and stabilization of the lumbosacral spine: literature review
}

\author{
E.S. Baykov, N.Yu. Verner
}

Novosibirsk Research Institute of Traumatology and Orthopaedics N.a. Ya.l. Tsivyan, Novosibirsk, Russian Federation

The literature review focuses on artificial intervertebral fusion. An increasing number of instrumented spinal procedures are performed each year with improved diagnostic and treatment strategies, advanced surgical technologies and optimal anesthetic techniques. One of the most common complications of spinal fusion is nonunion with the high reported incidence. Factors affecting fusion rates in lumbar spine surgery are described. Data from articles and textbooks of the last two decades have been used to reflect the current understanding of the research problem including reports in the earlier literature when appropriate.

Keywords: spondylodesis, lumbar spine, intervertebral fusion

\section{INTRODUCTION}

Spondylodesis is an effective spinal fusion surgery in the treatment of patients with intervertebral disc degeneration, spine deformities and traumatic injuries. An increasing number of instrumented spinal procedures are performed each year with improved diagnostic and treatment strategies, the overall increase in life expectancy, the availability of novel fusion techniques and optimal anesthetic technologies. Epidemiological study using the U.S. national administrative data showed a 2.4fold increase in the annual number of spinal fusion discharges, and a 2.7 -fold increase in primary lumbar fusion discharges between 1998 and 2008 [2]. The likelihood of reoperation following a lumbar spine operation can be substantial. Nonunion rates for surgical spine stabilization have been reported to be as great as $40 \%$. [3, 4]. Irmola T. et al. reported the cumulative reoperation rate of $12.5 \%$ at 2 years and nearly $20 \%$ at 4 years following instrumented lumbar spine fusion. The newer spine fusion techniques allow for improved fusion rates after surgical stabilization.

In 2011, Bridwell K.H. et al. detailed factors governing artificial spine fusion in the textbook of spinal surgery that included:

- bone graft or bone graft substitute: types of graft (cancellous or cortical bone), quantity of grafts used, preparation technique employed, etc.;

- fusion biomechanics: stability of fusion segment, loading and impaction of fusion segment, location of spondylodesis along spine, number of levels to be fused, efficacy of spinal immobilization, specific type of fusion (TLIF, PLIF, ALIF, LLIF);
- reliability of fixation for spondylodesis: preparation of fusion site, peculiarities of blood supply of soft tissues and fusion bed, previous surgery, local bone disease (e.g., infection), bone homeostasis;

- systemic factors: metabolic bone disease (e.g., osteoporosis), hormonal changes, drugs (corticosteroids), infections, smoking, nutritional status.

Spine fusion can be diagnosed with minimally invasive techniques and most common grading systems.

Bridwell et al. described a grading system for success in anterior interbody fusion in 1995. In 2007, Tan G.H. suggested grading fusion into one of four grades from complete fusion to bipolar pseudarthrosis. [9] Dynamics in bone-metal fusion can be well evaluated with grading system offered by I.A.Baulin et al. [10] who identified union of graft/implant and fusion bed. Fusion was recommended to be assessed at one year postsurgery considering physiological specific reparation of vertebral bone tissue.

\section{Osteoinductive materials}

The choice of graft material has profound implications for the success or failure of spondylodesis. The support of osteoinductive principles through the use of autograft would improve fusion. Allofenic bone grafts and other processed bone graft materials (recombinant morphogenetic protein, hydroxyapatite-, tricalcium phosphate-based biomaterials, their combinations) are used to fill the interbody cages or employed as a monocomponent to achieve fusion. Huang $\mathrm{H}$. et al. compared the process of substitution between allograft bone and local bone 
grafting in lumbar interbody fusion performed for transforaminal lumbar interbody fusion (TLIF) and transpedicular fixation employed for 81 patients. The mean area of bone mass in local bone grafting showed an almost 2-fold increase over that in the allograft bone at a 6- and 12-month follow-up demostrating superior osteoinductive properties. Comparative studies of autografts and calcium phosphate indicate to less osteoinductive properties of the latter. $\mathrm{M}$. Thaler et al. reported solid fusion with the use of calcium phosphate for posterior lumbar interbody fusion cages in nearly $30 \%$ at 1 year after surgery, and inadequate fusion was seen in $40 \%$ of the cases. The fusion rate of a hydroxyapatite biomaterial showed higher efficacy as compared to that of calcium phosphate in interbody fusion surgery. Kim D.H. reported no statistically significant differences in fusion status with different osteoinductive materials in lumbar interbody fusion surgery. The authors concluded that a greater initial stability of the anterior lumbar interbody fusion motion segment and minimum risk of subsidence can be achieved with parallel mediadorsal cages or media-ventral position converging to the center with fusion aided by posterior screw fixation.

Recombinant human bone morphogenetic protein (rhBMP) is known as the best bone graft substitute in spinal fusion. A retrospective study published in Spine journal in 2018 reported the fusion rate for the rhBMP and autograft groups being $92.7 \%$ and $92.3 \%$, respectively. Hueng DY et al. explored in vitro biomechanical effects of cage positions standalone and in posterior facet fixation providing stability for the motion within normal physiological limits [27]. The authors concluded that a greater initial stability of the anterior lumbar interbody fusion motion segment and minimum risk of subsidence can be achieved with parallel mediadorsal cages or media-ventral position converging to the center with fusion aided by posterior screw fixation.

\section{Biomechanical aspects of spondylodesis}

Implant size, the volume of osteoinductive material, adequate curettage are important for successful fusion. The parameters can be different depending on approaches to lumbar interbody fusion and surgical technique used: anterior (ALIF), lateral (LLIF), oblique (OLIF), transforaminal (TLIF) and posterior (PLIF). There are several advantages distinct to the ALIF approach: affords the surgeon control curettage, use larger cage and osteoinductive material of greater volume to facilitate fusion [17, 18, 20]. A benefit with LLIF includes placing an appropriately sized cage.
Which of the technologies can provide optimal conditions for interbody fusion? There is no definitive answer to the question. Findings are controversial. In a recent comparative analysis published in World Neurosurgery, no significant difference in fusion rates was demonstrated between ALIF, TLIF and PLIF at a 1-to-2-year follow-up.[20] ALIF provided the greatest amount of segmental and overall lumbar lordosis, TLIF resulted in less postoperative pain and PLIF showed a decreased implant subsidence rate. A meta-analysis published in 2017 did not show any significant differences between the groups (ALIF, PLIF, TLIF and LLIF) in terms of fusion rates. Implant subsidence is of major concern since the loss of angle correction and intervertebral disc space height due to subsidence may jeopardize the anatomic quality of the fusion. Implant subsidence encounters in $35 \%$ of the cases. Majority of the subsidence are reported to occur within the first 6-8 weeks after surgery with no progression onwards. Adverse events associated with fracture of the endplate during cage impaction include aggressive curettage, removal of the anterior longitudinal ligament, central cage location, use of bone graft alone, forced implant impaction, a small contact area between the cage and the endplate, and sagittal imbalance. Radiographic and clinical evaluation of cage subsidence reported in 2013 graded subsidence using the following scale: Grade I, $0 \%-24 \%$ loss of postoperative disc height; Grade II, $25 \%-49 \%$; Grade III, $50 \%-74 \%$; and Grade IV, $75 \%-100 \%$ [23].

The factors that were identified by Calvo-Echenique A. et al. as being most influential in minimizing implant subsidence included a wider cross-sectional cage size, greater interbody support to endplate, ventral cage placement and curvature congruence with the endplates. Lowe TG et al. used human cadaveric specimen to quantify the endplates resistance to compressive loads at six different endplate test positions with implants of different design and area (hollow or solid cylindrical indenters) and the effects of endplate, being partially or fully removed, on structural strength [25]. For all levels tested, the highest MLF occurred in the posterolateral region of the endplate. The lowest value occurred in the central region (by $38 \%$ ). A largerdiameter solid support had the greater maximum load to failure, and the ultimate compressive strength for maximum-diameter hollow indenters was significantly higher than solid indenters with the lower risk of subsidence. There was no significant reduction in the endplate strength with partial removal of the endplate providing good conditions for fusion. Ventral removal 
of endplates and posterolateral cage placement were found to be practical for PLIF and TLIF. At least a $30 \%$ of cage and endplate coverage indicated to a decreased subsidence rate.

There is increasing recognition of the importance of spinal sagittal alignment in relation to fusion rates.

The average load that can be applied to the ventral column of the thoracolumbar junction in 'argonomic' balance is about $3.5 \mathrm{Nm}$ that can increase to $35 \mathrm{Nm}$ with the lever ventrally increased by $10 \mathrm{~cm}$ from the gravitation line that interferes with fusion. Rao PJ et al. reported $10.2 \%$ rate of subsidence in 147 patients undergoing ALIF with a significant negative correlation between lumbar lordosis and the extent of subsidence (Pearson correlation $=-0.754$, $\mathrm{P}=0.012$ ) [22]. Hueng DY et al. explored in vitro biomechanical effects of cage positions standalone and in posterior facet fixation providing stability for the motion within normal physiological limits [27]. The authors concluded that a greater initial stability of the anterior lumbar interbody fusion motion segment and minimum risk of subsidence can be achieved with parallel mediadorsal cages or mediaventral position converging to the center with fusion aided by posterior screw fixation.

What is the role of posterior screw fixation for interbody fusion? In 2018, there was a research on biomechanical influence of anterior longitudinal ligament and pedicle screws on subsidence with the use of hyperlordotic cages. Transpedicular screw fixation significantly decreased the stress in endplates, cages and lowered facet contact force, thus reducing the likelihood of failure. Another series evaluated the stability of fusion constructs using TLIF technologies with unilateral or bilateral posterior instrumentation.

Polyetheretherketone (PEEK) rods have become available as an alternative to metal rods for use with pedicle screws to perform posterior lumbar fusion. Compared with the titanium rod, the less rigid PEEK rod may alter load-bearing and control abnormal motion, which in consequence may promote the intervertebral bone fusion rate according to Wolff's law. Several clinical studies concerning the use of PEEK rod systems for fusion procedure are available in the published literature, however, clinical outcomes are still controversial. Ormond DR et al. reported documented fusion rate of $89.3 \%$ in 42 patients who underwent single-level fixation using TLIF and semirigid rods being similar to that as compared to other instrumentation modalities.

Studies comparing titanium and PEEK focus on fusion rates and subsidence. PEEK and titanium cages are similar regarding fusion rates, however, there is a significant difference in subsidence rates. Subsidence remains a significant concern with titanium implants, but PEEK is much more promising in this area due to mechanical strength and elasticity close to those of the bone. Phan K. et al. prospectively evaluated outcomes of ALIF in normal-weight, over-weight and obese patients. Fusion rate was significantly lower for patients who were obese $(p=0.014)$ and $30 \%$ of obese patients experienced failed fusion [50].

\section{Disc space preparation for interbody fusion}

A thorough curettage of the disc space is essential for a solid fusion. To enable fusion, a sufficient amount of potentially osteogenic cells is necessary; therefore, bleeding bone must be present adjacent to the graft. Two techniques of endplate preparation can be distinguished. One includes deliberate endplate cavitation to provide a host bed of bleeding cancellous bone. The other technique involves excision of the cartilage endplate down to bleeding subchondral bone for the compressive strength and stiffness of the vertebral body. The two surgical concepts of in situ fusion or realignment are to be considered. Direct visualization of endplate preparation helps to avoid damage of endplates and ensures adequate disc preparations that can be provided with ventral approach. Endplates at the cranial vertebral aspect may be more susceptible to damage than caudal endplates because they are $40 \%$ thinner and supported by less dense trabecular bone that is to be considered while performing curettage. The authors compared outcomes of patients who had cage subsidence or screw loosening and those who did not. Subsidence was shown to have no influence on clinical and radiological outcomes but screw loosening significantly reduced the fusion success rate at one year postoperatively. Surgery is technically more challenging to perform in patients with morbid obesity and is associated with a significantly increased operative time, blood loss and a higher risk of postoperative complications (infection, venous thromboembolism, etc.) and can jeopardize longterm outcomes. Some authors reported a higher risk of subsidence and nonunion in obese patients [49, 50]. Phan K. et al. prospectively evaluated outcomes of ALIF in normal-weight, over-weight and obese patients. Fusion rate was significantly lower for patients who were obese $(p=0.014)$ and $30 \%$ of obese patients experienced failed fusion [50].

\section{Modic changes and interbody fusion}

Baseline characteristics of endplates may play a role in clinical outcomes of interbody fusion. Changes in 
signal intensity in vertebral endplates and subchondral bone marrow on magnetic resonance imaging (MRI) were first described and formally classified by Modic et al. in 1988. Based on their appearance in MRI images, Modic changes are pathophysiologically and morphologically classified into three types. Modic type 1 changes represent bone marrow oedema and inflammation; Modic type 2 changes represents marrow ischemia and the conversion of normal red haemopoietic bone marrow into yellow fatty marrow, and Modic type 3 changes are representive of subchondral bone sclerosis [41, 42]. Many authors suggest that all Modic changes can progress from one type to another type $[43,44]$. The natural conversion of Type I to Type II takes place over a year of interbody fusion. However, there are few studies evaluating interbody fusion in presence of different types of changes in the endplates and the adjacent red haemopoietic bone marrow. A higher nonunion rate is reported with baseline Modic type 1 changes with no stabilization performed. It can be suggested that the hypothesized natural history of vertebral endplate changes including microfractures of the endplate accompanied by increased vascular density along with an increase in the number of nerve endings and levels of proinflammatory mediators due to regular biomechanical stress facilitated better fusion in type I and type II. A further proportion of studies is needed for a higher evidence regarding correlation between different Modic types and bony fusion rates following spondylodesis procedure.

\section{Systemic factors}

Osteoporosis is a disorder characterized by reduced bone mass, impaired bone quality (microarchitechtonics), and a propensity to fracture [47]. The condition is currently a challenge for spinal surgeons. Spinal surgeries with pedicle screw fixation and interbody fusion for osteoporotic spine have risks of screw loosening and subsidence, which may require a reoperation. Cho $\mathrm{JH}$ et al detected that subsidence and screw loosening rates were significantly higher in osteoporotic patients who underwent single-level PLIF as compared to that in non-osteoporotic patients, but fusion rate did not differ between the groups at oneyear follow-up [48]. The authors compared outcomes of patients who had cage subsidence or screw loosening and those who did not. Subsidence was shown to have no influence on clinical and radiological outcomes but screw loosening significantly reduced the fusion success rate at one year postoperatively. Surgery is technically more challenging to perform in patients with morbid obesity and is associated with a significantly increased operative time, blood loss and a higher risk of postoperative complications (infection, venous thromboembolism, etc.) and can jeopardize long-term outcomes. Some authors reported a higher risk of subsidence and nonunion in obese patients $[49,50]$. Phan K. et al. prospectively evaluated outcomes of ALIF in normal-weight, over-weight and obese patients. Fusion rate was significantly lower for patients who were obese $(p=0.014)$ and $30 \%$ of obese patients experienced failed fusion [50].

Smoking is another systemic factor affecting successful interbody fusion. Many studies have stated that smoking increases the risk of pseudarthrosis and subsidence because nicotine induces tissue hypoxia and has toxic effect on osteoblast cells [51, 52]. Glassman SD et al. reported fusion achieved in $76.2 \%$ of smokers and in $94.1 \%$ of nonsmokers who underwent singlelevel instrumented lumbar fusion with use of the iliac crest bone graft at 2 years postoperatively. [53].

\section{CONCLUSION}

A successful spine fusion is a multifactorial process dependent on a number of local and systemic factors that affect the healing response. The factors include the use of osteoinductive materials, fusion techniques, systemic factors like osteoporosis, obesity, etc. and these have been discussed extensively in the literature but controversies still exist. Clinical and radiological outcomes of interbody fusion can be improved with piloting potential solutions for better patient experiences, quality of life and financial results. The routine spine surgery practices involve preoperative patient evaluation, surgical evaluation process, comprehensive preoperative medical review coupled with a technically immaculate surgical procedure and evidence-based proactive continuous improvement.

\section{REFERENCES}

1. Krutko A.V., Sanginov A.D. K voprosu ob obeme predoperatsionnykh radiologicheskogo I tomograficheskogo obsledovanii patsientov s degenerativnymi zabolevaniiami poiasnichnogo otdela pozvonochnika [On the problem of the volume of preoperative radiological and tomographic examinations of patients with degenerative diseases of the lumbar spine]. Khirurgiia Pozvonochnika, 2018, vol. 15, no. 2, pp. 66-75. (in Russian)

2. Rajaee S.S., Bae H.W., Kanim L.E., Delamarter R.B. Spinal fusion in the United States: analysis of trends from 1998 to 2008. Spine, 2012, vol. 37, no. 1, pp. 67-76. DOI: 10.1097/BRS.0b013e31820cccfb. 
3. Blumenthal S.L., Ohnmeiss D.D.; NASS. Intervertebral cages for degenerative spinal diseases. Spine J., 2003, vol. 3, no. 4, pp. 301-309.

4. Bridwell K.H., Sedgewick T.A., O'Brien M.F., Lenke L.G., Baldus C. The role of fusion and instrumentation in the treatment of degenerative spondylolisthesis with spinal stenosis. J. Spinal Disord., 1993, vol. 6, no. 6, pp. 461-472.

5. Irmola T.M., Häkkinen A., Järvenpää S., Marttinen I., Vihtonen K., Neva M. Reoperation Rates Following Instrumented Lumbar Spine Fusion. Spine, 2018, vol. 43, no. 4, pp. 295-301. DOI: 10.1097/BRS.0000000000002291.

6. Bridwell K.H., DeWald R.L., eds. The Textbook of Spinal Surgery. $3^{\text {rd }}$ Ed. Philadelphia PA, Lippincott Williams \& Wilkins, 2011.

7. Bridwell K.H., Lenke L.G., McEnery K.W., Baldus C., Blanke K. Anterior fresh frozen structural allografts in the thoracic and lumbar spine. Do they work if combined with posterior fusion and instrumentation in adult patients with kyphosis or anterior column defects? Spine, 1995, vol. 20, no. 12, pp. 1410-1418.

8. Vavruch L., Hedlund R., Javid D., Leszniewski W., Shalabi A. A prospective randomized comparison between the cloward procedure and a carbon fiber cage in the cervical spine: a clinical and radiologic study. Spine, 2002, vol. 27, no. 16, pp. 1694-1701.

9. Tan G.H., Goss B.G., Thorpe P.J., Williams R.P. CT-based classification of long spinal allograft fusion. Eur. Spine J., 2007, vol. 16, no. 11 , pp. 1875-1881.

10.Baulin I.A., Gavrilov P.V., Sovetova N.A., Mushkin A.Iu. Luchevoi analiz formirovaniia kostnogo bloka pri ispolzovanii razlichnykh materialov dlia perednego spondilodeza $u$ patsientov $s$ infektsionnym spondilitom [Radiation analysis of bone block formation when using various materials for anterior spondylodesis in patients with infection spondylitis]. Khirurgiia Pozvonochnika, 2015, vol.12, no. 1, pp. 83-89. (in Russian) Available at: https://doi.org/10.14531/ss2015.1.83-89.

11.Tsivyan Ia.L., Ramikh E.A., Mikhailovskii M.V. Reparativnaia regeneratsiia tela slomannogo pozvonka [Reparative regeneration of the body of a fractured vertebra]. Borodin Iu.I., ed. Novosibirsk, Nauka,1985, 183 p. (in Russian)

12.Huang H., Jiang C., Feng Z., Jiang X. Comparing the process of creeping substitution between allograft bone and local bone grafting in lumbar interbody fusion. Eur. Spine J., 2014, vol. 23, no. 10, pp. 2068-2074. DOI: 10.1007/s00586-014-3388-6.

13.Thaler M., Lechner R., Gstöttner M., Kobel C., Bach C. The use of beta-tricalcium phosphate and bone marrow aspirate as a bone graft substitute in posterior lumbar interbody fusion. Eur. Spine J., 2013, vol. 22, no. 5, pp. 1173-1182. DOI: 10.1007/s00586-012-2541-3.

14.Kim D.H., Lee N., Shin D.A., Yi S., Kim K.N., Ha Y. Matched Comparison of Fusion Rates between Hydroxyapatite Demineralized Bone Matrix and Autograft in Lumbar Interbody Fusion. J. Korean Neurosurg. Soc., 2016, vol. 59, no. 4, pp. 363-367. DOI: 10.3340/ jkns.2016.59.4.363.

15.Khan T.R., Pearce K.R., McAnany S.J., Peters C.M., Gupta M.C., Zebala L.P. Comparison of transforaminal lumbar interbody fusion outcomes in patients receiving rhBMP-2 versus autograft. Spine J., 2018, vol. 18, no. 3, pp. 439-446. DOI: 10.1016/j. spinee.2017.08.230.

16.Ye F., Zeng Z., Wang J., Liu H., Wang H., Zheng Z. Comparison of the use of rhBMP-7 versus iliac crest autograft in singlelevel lumbar fusion: a meta-analysis of randomized controlled trials. J. Bone Miner. Metab., 2018, vol. 36, no. 1, pp. 119-127. DOI: 10.1007/s00774-017-0821-z.

17.Schroeder G.D., Kepler C.K., Millhouse P.W., Fleischman A.N., Maltenfort M.G., Bateman D.K., Vaccaro A.R. L5/S1 Fusion Rates in Degenerative Spine Surgery:Systematic Review Comparing ALIF, TLIF, and Axial Interbody Arthrodesis. Clin. Spine Surg., 2016, vol. 29, no. 4, pp. 150-155. DOI: 10.1097/BSD.0000000000000356.

18.Bulatov A.V., Klimov V.S., Evsiukov A.V. Khirurgicheskoe lechenie spondilolistezov nizkoi stepeni gradatsii: sovremennoe sostoianie problemy [Sugical treatment of spondylolistheses of low degree of gradation: current state of the problem]. Khirurgiia Pozvonochnika, 2016, vol. 13, no. 3, pp. 68-77. (in Russian) Available at: https://doi.org/10.14531/ss2016.3.68-77.

19.Lee C.W., Yoon K.J., Ha S.S. Which Approach Is Advantageous to Preventing Development of Adjacent Segment Disease? Comparative Analysis of 3 Different Lumbar Interbody Fusion Techniques (ALIF, LLIF, and PLIF) in L4-5 Spondylolisthesis. World Neurosurg., 2017, vol. 105, pp. 612-622. DOI: 10.1016/j.wneu.2017.06.005.

20.Lee N., Kim K.N., Yi S., Ha Y., Shin D.A., Yoon D.H., Kim K.S. Comparison of Outcomes of Anterior, Posterior, and Transforaminal Lumbar Interbody Fusion Surgery at a Single Lumbar Level with Degenerative Spinal Disease. World Neurosurg., 2017, vol. 101, pp. 216-226. DOI: 10.1016/j.wneu.2017.01.114.

21.Teng I., Han J., Phan K., Mobbs R. A meta-analysis comparing ALIF, PLIF, TLIF and LLIF. J. Clin. Neurosci., 2017, vol. 44, pp. 1117. DOI: $10.1016 /$ j.jocn.2017.06.013.

22.Rao P.J., Phan K., Giang G., Maharaj M.M., Phan S., Mobbs R.J. Subsidence following anterior lumbar interbody fusion (ALIF): a prospective study. J. Spine Surg., 2017, vol. 3, no. 2, pp. 168-175. DOI: 10.21037/jss.2017.05.03.

23.Marchi L., Abdala N., Oliveira L., Amaral R., Coutinho E., Pimenta L. Radiographic and clinical evaluation of cage subsidence after stand-alone lateral interbody fusion. J. Neurosurg. Spine, 2013, vol. 19, no. 1, pp. 110-118. DOI: 10.3171/2013.4.SPINE12319.

24.Calvo-Echenique A., Cegoñino J., Chueca R., Pérez-Del Palomar A. Stand-alone lumbar cage subsidence: A biomechanical sensitivity study of cage design and placement. Comput. Methods Programs Biomed., 2018, vol. 162, pp. 211-219. DOI: 10.1016/j. cmpb.2018.05.022.

25.Lowe T.G., Hashim S., Wilson L.A., O'Brien M.F., Smith D.A., Diekmann M.J., Trommeter J. A biomechanical study of regional endplate strength and cage morphology as it relates to structural interbody support. Spine, 2004, vol. 29, no. 21, pp. $2389-2394$.

26.Le Huec J.C., Richards J., Tsoupras A., Price R., Léglise A., Faundez A.A. The mechanism in junctional failure of thoraco-lumbar fusions. Part I: Biomechanical analysis of mechanisms responsible of vertebral overstress and description of the cervical inclination angle (CIA). Eur. Spine J., 2018, vol. 27, no. Suppl. 1, pp. 129-138. DOI: 10.1007/s00586-017-5425-8.

27.Hieng D.Y., Chung T.T., Chuang W.H., Hsu C.P., Chou K.N., Lin S.C. Biomechanical effects of cage positions and facet fixation on initial stability of the anterior lumbar interbody fusion motion segment. Spine, 2014, vol. 39, no. 13, pp. E770-E776. DOI: 10.1097/ BRS.0000000000000336.

28.Zhang Z., Fogel G.R., Liao Z., Sun Y., Sun X., Liu W. Biomechanical evaluation of four surgical scenarios of lumbar fusion with hyperlordotic interbody cage: A finite element study. Biomed. Mater. Eng., 2018, vol. 29, no. 4, pp. 485-497. DOI: 10.3233/BME-181004.

29.Ambati D.V., Wright E.K. Jr., Lehman R.A. Jr., Kang D.G., Wagner S.C., Dmitriev A.E. Bilateral pedicle screw fixation provides superior biomechanical stability in transforaminal lumbar interbody fusion: a finite element study. Spine J., 2015, vol. 15, no. 8, pp. 1812-1822. DOI: 10.1016/j.spinee.2014.06.015.

30.Lee D.Y., Park Y.J., Song S.Y., Jeong S.T., Kim D.H. Risk Factors for Posterior Cage Migration after Lumbar Interbody Fusion Surgery. Asian Spine J., 2018, vol. 12, no. 1, pp. 59-68. DOI: 10.4184/asj.2018.12.1.59. 
31.Ormond D.R., Albert L. Jr, Das K. Polyetheretherketone (PEEK) Rods in Lumbar Spine Degenerative Disease: A Case Series. Clin. Spine Surg., 2016, vol. 29, no. 7, pp. E371-E375. DOI: 10.1097/BSD.0b013e318277cb9b.

32.Selim A., Mercer S., Tang F. Polyetheretherketone (PEEK) Rods for Lumbar Fusion: A Systematic Review and Meta-Analysis. Int. J. Spine Surg., 2018, vol. 12, no. 2, pp. 190-200. DOI: 10.14444/5027.

33.Chou Y.C., Chen D.C., Hsieh W.A., Chen W.F., Yen P.S., Harnod T., Chiou T.L., Chang Y.L., Su C.F., Lin S.Z., Chen S.Y. Efficacy of anterior cervical fusion: comparison of titanium cages, polyetheretherketone (PEEK) cages and autogenous bone grafts. J. Clin. Neurosci., 2008, vol. 15, no. 11, pp. 1240-1245. DOI: 10.1016/j.jocn.2007.05.016.

34.Niu C.C., Liao J.C., Chen W.J., Chen L.H. Outcomes of interbody fusion cages used in 1 and 2-levels anterior cervical discectomy and fusion: titanium cages versus polyetheretherketone (PEEK) cages. J. Spinal Disord. Tech., 2010, vol. 23, no. 5, pp. 310-316. DOI: 10.1097/BSD.0b013e3181af3a84.

35.Nemoto O., Asazuma T., Yato Y., Imabayashi H., Yasuoka H., Fujikawa A. Comparison of fusion rates following transforaminal lumbar interbody fusion using polyetheretherketone cages or titanium cages with transpedicular instrumentation. Eur. Spine J., 2014, vol. 23, no. 10, pp. 2150-2155. DOI: 10.1007/s00586-014-3466-9.

36.Schimmel J.J., Poeschmann M.S., Horsting P.P., Schönfeld D.H., Van Limbeek J., Pavlov P.W. PEEK Cages in Lumbar Fusion: Mid-term Clinical Outcome and Radiologic Fusion. Clin. Spine Surg., 2016, vol. 29, no. 5, pp. E252-E258. DOI: 10.1097/ BSD.0b013e31826eaf74.

37.Seaman S., Kerezoudis P., Bydon M., Torner J.C., Hitchon P.W. Titanium vs. polyetheretherketone (PEEK) interbody fusion: Metaanalysis and review of the literature. J. Clin. Neurosci., 2017, vol. 44, pp. 23-29. DOI: 10.1016/j.jocn.2017.06.062.

38.Polikeit A., Ferguson S.J., Nolte L.P., Orr T.E. The importance of the endplate for interbody cages in the lumbar spine. Eur. Spine J., 2003, vol. 12, no. 6, pp. 556-561.

39.Grant J.P., Oxland T.R., Dvorak M.F. Mapping the structural properties of the lumbosacral vertebral endplates. Spine, 2001, vol. 26, no. 8. P. 889-896.

40.Le T.V., Baaj A.A., Dakwar E., Burkett C.J., Murray G., Smith D.A., Uribe J.S. Subsidence of polyetheretherketone intervertebral cages in minimally invasive lateral retroperitoneal transpsoas lumbar interbody fusion. Spine, 2012, vol. 37, no. 14, pp. $1268-1273$. DOI: 10.1097/BRS.0b013e3182458b2f.

41.Modic M.T., Masaryk T.J., Ross J.S., Carter J.R. Imaging of degenerative disk disease. Radiology, 1988, vol. 168, no. 1, pp. 177186. DOI: 10.1148/radiology.168.1.3289089.

42.Modic M.T., Steinberg P.M., Ross J.S., Masaryk T.J., Carter J.R. Degenerative disk disease: assessment of changes in vertebral body marrow with MR imaging. Radiology, 1988, vol. 166, no. 1, Pt. 1, pp. 193-199. DOI: 10.1148/radiology.166.1.3336678.

43.Ohtori S., Yamashita M., Yamauchi K., Inoue G., Koshi T., Suzuki M., Orita S., Eguchi Y., Ochiai N., Kishida S., Takaso M., Kuniyoshi K., Ishikawa T., Arai G., Miyagi M., Kamoda H., Nakamura J., Aoki Y., Takahashi K. Change in Modic type 1 and 2 signals after posterolateral fusion surgery. Spine, 2010, vol. 35, no. 12, pp. 1231-1235. DOI: 10.1097/BRS.0b013e3181bde562.

44.Portella S.T., Acioly M.A. The course of Modic vertebral body changes after posterolateral lumbar fusion on fused and adjacent levels: A systematic review of the literature. J. Clin. Neurosci., 2017, vol. 41, pp. 6-10. DOI: 10.1016/j.jocn.2017.04.007.

45.Lang P., Chafetz N., Genant H.K., Morris J.M. Lumbar spinal fusion. Assessment of functional stability with magnetic resonance imaging. Spine, 1990, vol. 15, no. 6, pp. 581-588.

46.Kwon Y.M., Chin D.K., Jin B.H., Kim K.S., Cho Y.E., Kuh S.U. Long Term Efficacy of Posterior Lumbar Interbody Fusion with Standard Cages alone in Lumbar Disc Diseases Combined with Modic Changes. J. Korean Neurosurg. Soc., 2009, vol. 46, no. 4, pp. 322-327. DOI: 10.3340/jkns.2009.46.4.322.

47.Lesniak O.M., Benevolenskaia L.I. Osteoporoz v Rossiiskoi Federatsii: problemy i perspektivy [Osteoporosis in the Russian Federation: problems and perspectives]. Nauchno-Prakticheskaia Revmatologiia, 2010, no. 5, pp. 14-18. (in Russian)

48.Cho J.H., Hwang C.J., Kim H., Joo Y.S., Lee D.H., Lee C.S. Effect of osteoporosis on the clinical and radiological outcomes following one-level posterior lumbar interbody fusion. J. Orthop. Sci., 2018, vol. 23, no. 6, pp. 870-877. DOI: 10.1016/j.jos.2018.06.009.

49.Behrbalk E., Uri O., Parks R.M., Musson R., Soh R.C., Boszczyk B.M. Fusion and subsidence rate of stand alone anterior lumbar interbody fusion using PEEK cage with recombinant human bone morphogenetic protein-2. Eur. Spine J., 2013, vol. 22, no. 12, pp. 2869-2875. DOI: 10.1007/s00586-013-2948-5.

50.Phan K., Rogers P., Rao P.J., Mobbs R.J. Influence of obesity on complications, clinical outcome, and subsidence after anterior lumbar interbody fusion (ALIF): prospective observational study. World Neurosurg., 2017, vol. 107, pp. 334-341. DOI: 10.1016/j. wneu.2017.08.014.

51.Lau D., Berger M.S., Khullar D., Maa J. The impact of smoking on neurosurgical outcomes. J. Neurosurg., 2013, vol. 119, no. 5, pp. 1323-1330. DOI: 10.3171/2013.5.JNS122287.

52.Malham G.M., Parker R.M., Blecher C.M., Seex K.A. Assessment and classification of subsidence after lateral interbody fusion using serial computed tomography. J. Neurosurg. Spine, 2015, vol. 23, no. 5, pp. 589-597. DOI: 10.3171/2015.1.SPINE14566.

53.Glassman S.D., Dimar J.R. 3rd, Burkus K., Hardacker J.W., Pryor P.W., Boden S.D., Carreon L.Y. The efficacy of rhBMP-2 for posterolateral lumbar fusion in smokers. Spine, 2007, vol. 32, no. 15, pp. 1693-1698.

Рукопись поступила 15.04.2019

\section{Information about the authors:}

1. Evgeny S. Baikov, M.D., Ph.D.,

Novosibirsk Research Institute of Traumatology and Orthopaedics N.a. Ya.l. Tsivyan, Novosibirsk, Russian Federation,

Email: evgen-bajk@mail.ru.

2. Natalya Yu. Werner, M.D.,

Novosibirsk Research Institute of Traumatology and Orthopaedics N.a. Ya.l. Tsivyan, Novosibirsk, Russian Federation,

Email: n.verner.n@yandex.ru 